\title{
Capacity of Air-and-Screen Grain Cleaner as Component of Production Line of Sunflower Meal
}

\author{
Igor Evgenievich Priporov, Vladimir Stanislavovich Kurasov, Mikhail Ivanovich Chebotarev, Anatoliy \\ Dmitrievich Gumbarov, Evgeny Vladimirovich Kuznetsov \\ Kuban State Agrarian University, Russia
}

\begin{abstract}
This work is aimed at determination of efficient capacity of an MVU-1500 air-and-screen grain cleaner at which extruder would process fed stock on the basis of designed multifactor experiment. On the basis of implementation of planning matrix, the mathematical model of the second order has been developed for determination of capacity of MVU-1500 air-and-screen grain cleaner upon classification of a heap of sunflower seeds. The maximum capacity of MVU-1500 air-and-screen grain cleaner upon classification of a heap of sunflower seeds in the section of optimum region with regard to feeding rate $\left(C_{0}\right)$ of a heap of sunflower seeds into pneumatic channel, oscillation frequency $(n)$ of cleaner shoe, and air flow rate $(v)$ in the pneumatic channel of final aspiration at zero level is $931 \mathrm{~kg} / \mathrm{h}$; the optimum parameters of these factors have been determined.
\end{abstract}

Key words: capacity of air-and-screen grain cleaner, extruder, feeding rate of a heap of seed, air flow rate.

\section{INTRODUCTION}

Small agricultural companies involved in processing of oil seeds (sunflower, soya, lint, rapeseed, and others) using MVU-1500 air-and-screen grain cleaners sometimes should process wastes remained after postharvest handling of seeds (sunflower, for instance). These wastes could be used for production of feed additives upon cattle fattening (large cattle, pigs, and others), this stock also contains organic impurities: fragmented inflorescences and stems as well as husked, shrunk, and fractured sunflower seeds. After classification of a heap of sunflower seeds on MVU-1500 air-and-screen grain cleaners, the seeds of main culture generally contain organic impurities (Table 1).

Table 1. Main indices of classification quality of Lakomka sunflower seeds using a serial MVU-1500 air-and-screen grain cleaner (production rate: $1.40 \mathrm{t} / \mathrm{h}$ ) [, 2].

The data in Table 1 demonstrate that as a consequence of inefficient operation of pneumatic channel of final aspiration, the material purity is $97.61 \%$, which does not meet the requirements of GOST Standard for seed material. The content of wastes is $2.39 \%$ [1, 3-7]. The quality of seed material corresponds to Class 3 .

Herewith, the seed material can be used as feed or as seed material after further processing in order to obtain seeds of Class 1 (2) in terms of purity. While considering the seed material, Class 3, containing organic impurities, and the seeds of main culture as feed obtained by extruders, the attention should be paid to improvement of its quality, mainly to increase in the content of protein and amino acids.

The studies by Loshkomoinikov have demonstrated that the deficiency of protein and amino acids in cattle feeds in winters exceeds $30 \%$. Provision of protein in the feeds on the basis of scientifically substantiated animal health standards without increase in the content results in improvement of economic efficiency of cattle breeding. Provision of animals with protein in accordance with the substantiated standards is an important problem of successful development of cattle breeding. Production of protein can be increased using oil clusters (sunflower, rapeseeds, lint, and others), which combine productivity of seeds with high content of oil and protein upon its optimum balance in terms of amino acids composition. The products of processing of oil seeds are cakes and meals of various agricultural crops required for feeding cattle and poultry. Nowadays all favorable conditions for wide use of oil seed meals as feeds are available [8-14].

The requirements to improvement of production of protein feeds based on oil seeds (sunflower), sunflower meal in particular, are increasingly high [15-20].

The pelletizing line of sunflower meal is known (Fig. 1) where shell-shaped meal is supplied to the milling section where it is milled to groats with the size less than $3 \mathrm{~mm}$ and then, via cyclone, to intermediate silo for storage. A magnetic separator is installed prior to the pelletizer where the groats are cleaned. Then the groats are weighed and fed to continuous mixer for mixing and steam processing in order to achieve homogeneous and plastic product. Addition of steam promotes decrease in energy consumption, decrease in wear of working elements of pressing pelletizer. The prepared 
product is fed to the pressing pelletizer. Pelletizing is performed in the pressing chamber due to pressing by rollers between holes of rotating matrix.
Hot pellets (about $80^{\circ} \mathrm{C}$ ) are cooled by air in countercurrent cooler to the temperature required for extraction: $55-60^{\circ} \mathrm{C}$. The cooled particles after discharging from the cooler are separated from fines on the screen and are supplied to the extractor room, and the fines are supplied to repeated pelletizing [21-25].

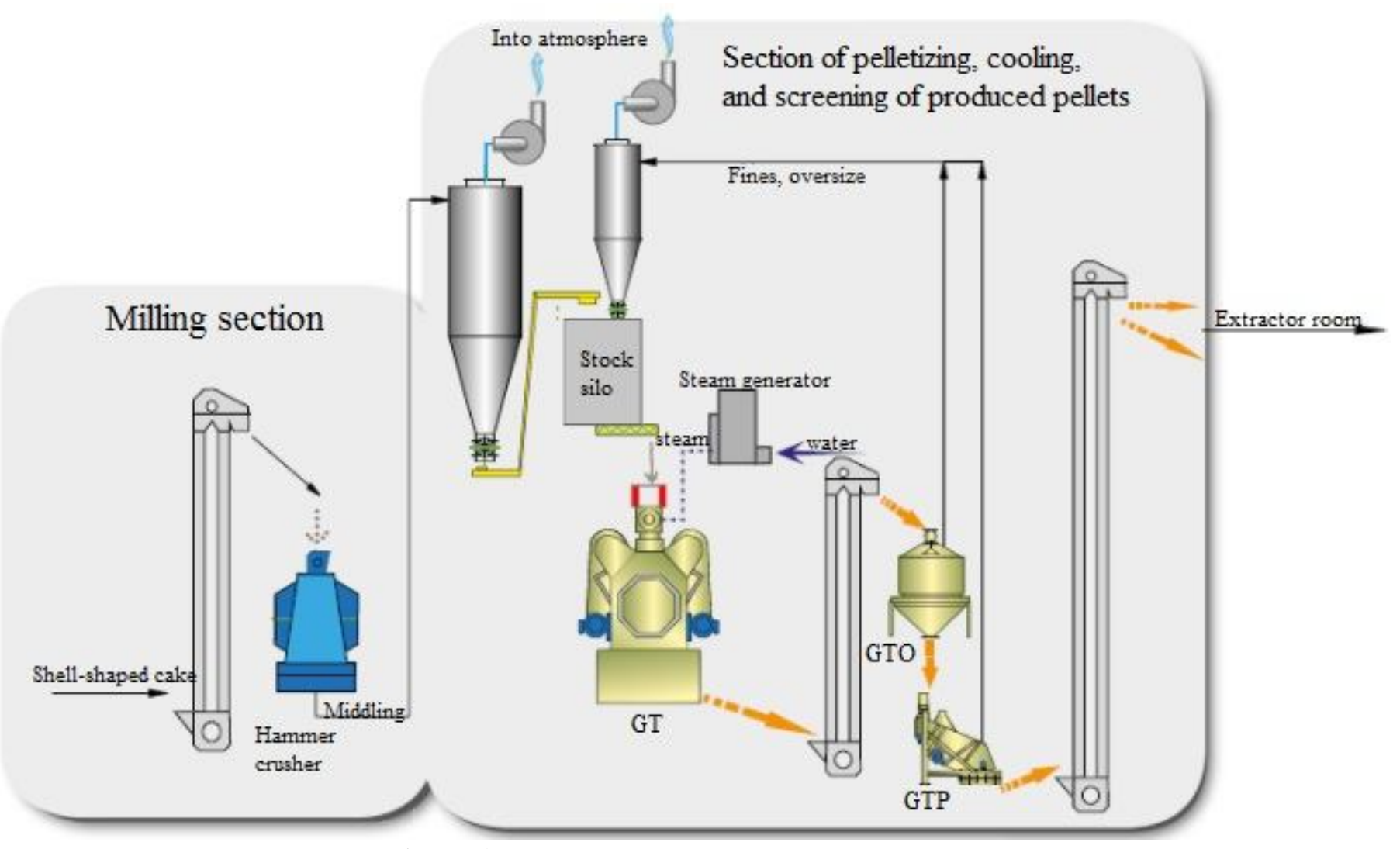

Figure 1: Pelletizing of sunflower meal by ICK Group.

Another process line for small agricultural companies made according to RF Patent 2328171 [22, 26-29] with efficient equipment arrangement, was developed (Fig. 2), exergy analysis of production processes of complete combined feeds was carried out. The proposed production line of coextruded feeds is based on the concepts of efficient resource saving allowing to increase nutrition value of the combined feeds by purposeful adjustment of content of various components as well as to decrease significantly the expenses for raw stock while obtaining high quality products.

Application of the proposed integrated systems in combination with the main production technology of combined feeds makes it possible to improve technical and economical performances, and to develop real possibilities to save resources and to improve quality of final products [30-34]. 


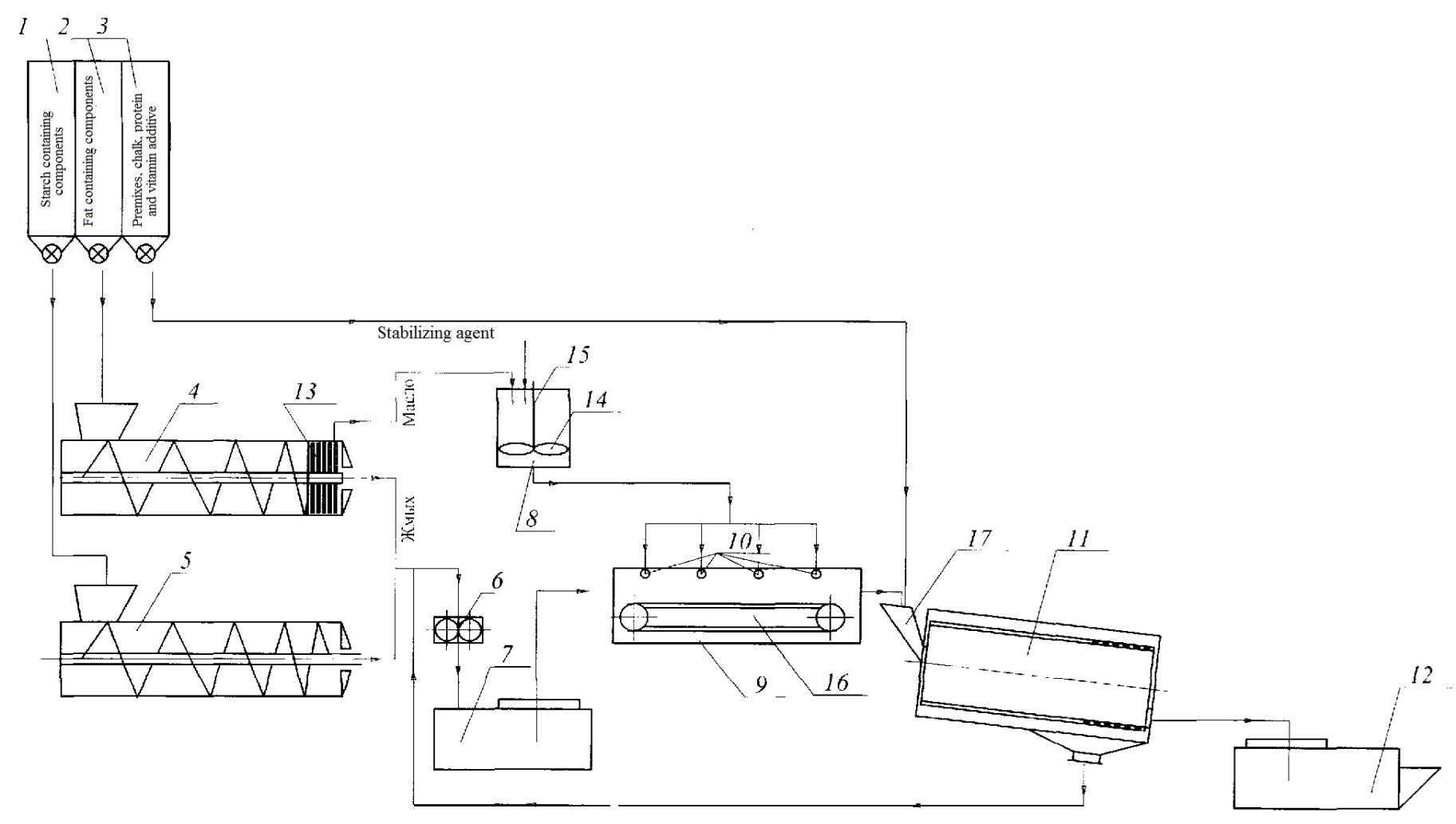

Figure 2:. Production line of coextruded feeds.

The technology can be improved by combination of two procedures (postharvest processing of a heap of sunflower seeds using air-and-screen grain cleaner and its extrusion to produce protein feed).

The productivity of MVU-1500 air-and-screen grain cleaner is $1.4 \mathrm{t} / \mathrm{h}$ upon classification of a heap of sunflower seeds, and the productivity of KMZ-2 is $0.25-0.60 \mathrm{t} / \mathrm{h}$, thus it is required to equalize these performances for efficient operation of the extruder, since it can fail to process the fed material (organic impurity and seeds of main culture) and to produce high quality protein feed: sunflower meal.

This work is aimed at determination of efficient capacity of an MVU-1500 air-and-screen grain cleaner at which extruder would process fed stock on the basis of designed multifactor experiment

\section{METHODS}

Aiming at equalization of productivities of MVU-1500 air-and-screen grain cleaner and KMZ-2 extruder, the method of protein feed production was developed according to RF Patent 2636474 [35], it is performed as follows [36].

The components of a heap of Lakomka sunflower seeds, comprised of fragmented inflorescences, stems and sunflower seeds, are processed on the screens and in the pneumatic channels of preliminary and final aspiration of the machine 1 . After secondary processing, the fragmented inflorescences, stems and sunflower seeds are extruded in the extruder 2 . The rate of their addition into the vertical air flow of the final aspiration pneumatic channel should be by 2.3-5.6 times lower than that of discharge of final product upon extrusion. If the feeding rate to the final aspiration pneumatic channel is less than 2.3 times, then the material would not be fed into the extruder in full amounts and it will be idle with possible failure, and if it is higher than 5.6 times, the extruder will be unable to process the material, thus deteriorating the quality of feed and its nutritional properties (Fig. 3). 


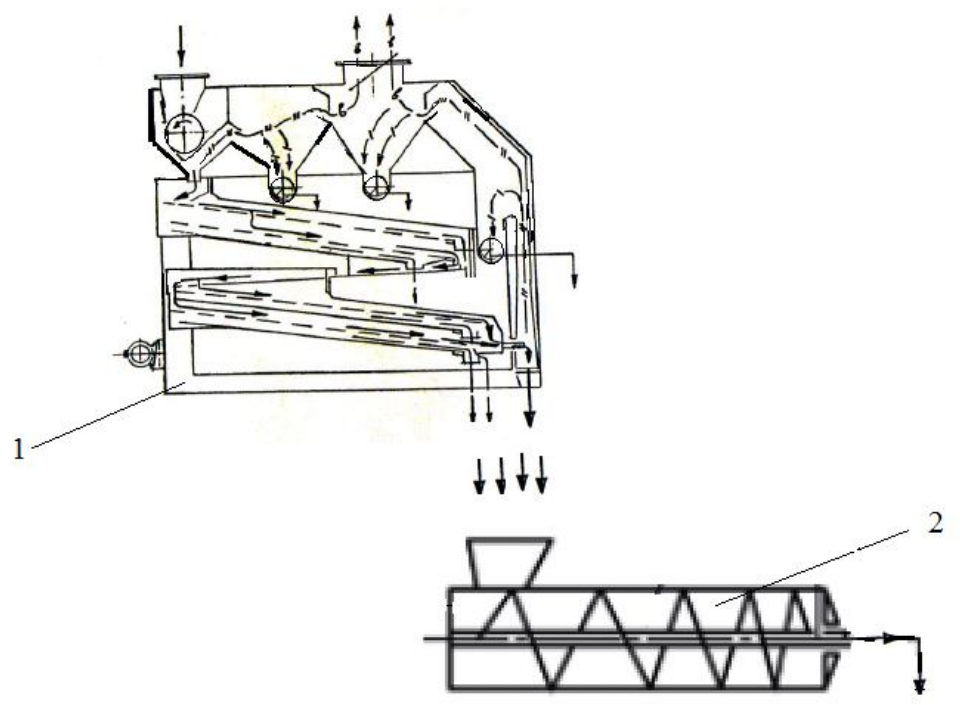

Figure 3: Schematic view of production of protein feed

Production of protein feed can be exemplified as follows. The components of a heap of Lakomka sunflower seeds, comprised of fragmented inflorescences, stems and sunflower seeds, are fed into an MVU-1500 air-and-screen grain cleaner comprised of the silo, the gate, the pneumatic channels of preliminary and final aspiration. The material feeding into the machine of secondary cleaning is adjusted by the gate between the silo and the feeding roller. After cleaning of a heap of sunflower seeds, in the pneumatic channel of preliminary aspiration and on screens there are remained sunflower seeds and fragmented inflorescences and stems which are supplied to the pneumatic channel of final aspiration and further to a KMZ-2 extruder. The rate of their addition into the vertical air flow of the final aspiration pneumatic channel should be by 2.3-5.6 times lower than that of discharge of final product upon extrusion.

The intervals of factor variations were determined on the basis of the experiments [1]. The following parameters were selected as variables: $x_{1}-$ the feeding rate of sunflower seeds into pneumatic channel, $\mathrm{m} / \mathrm{s} ; x_{2}$ - the oscillation frequency of cleaner shoe, $\min ^{-1} ; x_{3}$ - the air flow rate in the pneumatic channel of final aspiration, $\mathrm{m} / \mathrm{s}$. The resulting optimization criterion is the productivity of MVU-1500 air-and-screen grain cleaner upon classification of a heap of sunflower seeds $y_{1}, \mathrm{~kg} / \mathrm{h}$.

The three-level second-order Box-Behnken design was implemented [1]. The experiment design and the variation levels of factors are summarized in Table 1.

Table 1: Box-Behnken design and variation levels of factors

\begin{tabular}{|c|c|c|c|c|}
\hline \multirow{3}{*}{ Notation } & \multicolumn{3}{|l|}{ Factor } & Optimization criterion \\
\hline & $\begin{array}{lrr}\text { Feeding } & \text { rate } & \text { of } \\
\text { sunflower seeds into } \\
\text { pneumatic channel }\left(\mathrm{C}_{0}\right)\end{array}$ & \begin{tabular}{l}
\multicolumn{1}{c}{ Oscillation } \\
frequency of \\
cleaner shoe $(n)$
\end{tabular} & $\begin{array}{l}\text { Air flow rate in } \\
\text { pneumatic channel of } \\
\text { final aspiration }\end{array}$ & $\begin{array}{l}\text { Production rate of } \\
\text { MVU-1500 air-and-screen } \\
\text { grain cleaner }(v)\end{array}$ \\
\hline & $x_{1}, \mathrm{~m} / \mathrm{s}$ & $x_{2}, \min ^{-1}$ & $x_{3}, \mathrm{~m} / \mathrm{s}$ & $y_{1}, \mathrm{~kg} / \mathrm{h}$ \\
\hline Upper level (+1) & 0.084 & 360 & 5.22 & \\
\hline Main level (0) & 0.060 & 320 & 4.5 & \\
\hline Lower level $(-1)$ & 0.036 & 280 & 3.78 & \\
\hline \multicolumn{5}{|l|}{ Design matrix } \\
\hline 1 & + & + & 0 & 3,000 \\
\hline 2 & - & - & 0 & 1,200 \\
\hline 3 & + & - & 0 & 2,200 \\
\hline 4 & - & + & 0 & 1,200 \\
\hline 5 & 0 & 0 & + & 1,800 \\
\hline 6 & 0 & 0 & - & 1,700 \\
\hline 7 & 0 & 0 & + & 1,000 \\
\hline 8 & 0 & 0 & - & 950 \\
\hline
\end{tabular}


Igor Evgenievich Priporov et al., International Journal of Emerging Trends in Engineering Research, 8(1), January 2020,157 - 163

\begin{tabular}{|l|l|l|l|l|}
\hline 9 & 0 & 0 & 0 & 900 \\
\hline 10 & + & 0 & + & 1,000 \\
\hline 11 & - & 0 & - & 800 \\
\hline 12 & + & 0 & - & 750 \\
\hline 13 & - & 0 & + & 1,300 \\
\hline 14 & 0 & + & 0 & 1,050 \\
\hline
\end{tabular}

\section{RESULT ANS DISCUSSION}

After implementation of the experiment design matrix, the regression coefficients were calculated by the procedure described in [37]. The obtained regression coefficients were substituted into the mathematical model for prediction of productivity of MVU-1500 air-and-screen grain cleaner upon classification of a heap of sunflower seeds $\left(y_{1}\right)$ :

$y_{1}=908.4+306.4 x_{1}+122.8 x_{2}+109.2 x_{2}+181.9 x_{1} x_{2}-27.3 x_{1} x_{2}$

$$
-52.6 x_{1}^{2}+1,136 x_{2}^{2}+730.5 x_{3}^{2}
$$

where $x_{1}$ was the feeding rate of sunflower seeds into pneumatic channel, $\mathrm{m} / \mathrm{s} ; x_{2}$ was the oscillation frequency of cleaner shoe, $\min ^{-1} ; x_{3}$ was the air flow rate in pneumatic channel of final aspiration, $\mathrm{m} / \mathrm{s}$.

On the basis of Eq. (1), it is possible to conclude that the increase in the considered parameters $\left(x_{1}, x_{2}, x_{3}\right)$ leads to increase in the optimization criterion $\left(y_{1}\right)$.

Aiming at verification of adequacy hypothesis of the -sedond? 20 rđer models, the regression equations (1) were statistically analyzed.

The adequacy of the second-order models was verified by Fisher test aided by auxiliary Table 3 where the optimization criterion was determined by Eq. (1).

Table 2: Auxiliary table for prediction of experimental F-test

\begin{tabular}{|l|l|l|l|l|}
\hline test \# & $\bar{y}$ & $\hat{y}$ & $|\hat{y}-\bar{y}|$ & $(\hat{y}-\bar{y})^{2}$ \\
\hline 1 & 2,900 & 3,000 & 100 & 10,000 \\
\hline 2 & 1,350 & 1,200 & 150 & 22,500 \\
\hline 3 & 2,300 & 2,200 & 100 & 10,000 \\
\hline 4 & 1,500 & 1,200 & 300 & 90,000 \\
\hline 5 & 1,850 & 1,800 & 50 & 2,500 \\
\hline 6 & 1,620 & 1,700 & 80 & 6,400 \\
\hline 7 & 986 & 1,000 & 14 & 196 \\
\hline 8 & 940 & 950 & 10 & 100 \\
\hline 9 & 1,050 & 900 & 150 & 22,500 \\
\hline 10 & 1,200 & 1,000 & 200 & 40,000 \\
\hline 11 & 860 & 800 & 60 & 3,600 \\
\hline 12 & 820 & 750 & 70 & 4,900 \\
\hline 13 & 1,320 & 1,300 & 20 & 400 \\
\hline 14 & 985 & 1,050 & 65 & 4,225 \\
\hline Sum & & & 217,321 \\
\hline
\end{tabular}

On the basis of Table 2, the residual sum of squares is determined which is $\mathrm{SS}_{\mathrm{R}}=217,321$ for productivity.

The sum of squares related with the dispersion characterizing experimental error is $\mathrm{SS}_{\mathrm{E}}=15,522.9$ for productivity.

The sum of squares related with the inadequacy dispersion [37] is $\mathrm{SS}_{\mathrm{LF}}=24,146.8$ for productivity.

The optimization criterion experimentally determined in [37] is 1.56 . The reference value of F-criterion at $5 \%$ significance is 2.70 .
Since $F_{\text {exp }}<F_{0.05}$, then the adequacy hypothesis of Eq. (1) is valid and the experimental results are considered as valid with $95 \%$ probability.

With the aim of analysis and systemization, the second-order equation is reduced to canonic form by its differentiation [37, 38].

The regression equation (1) reduced to canonic form is as follows:

$Y-931=-52.6 X_{1}^{2}+480.5 X_{2}^{2}+1,386 X_{3}^{2}$. 
Igor Evgenievich Priporov et al., International Journal of Emerging Trends in Engineering Research, 8(1), January 2020,157 - 163

\section{CONCLUSION}

The maximum capacity of MVU-1500 air-and-screen grain cleaner upon classification of a heap of sunflower seeds in the section of optimum region with regard to feeding rate $\left(C_{0}\right)$ of a heap of sunflower seeds into pneumatic channel, oscillation frequency $(n)$ of cleaner shoe, and air flow rate $(v)$ in the pneumatic channel of final aspiration at zero level is 931 $\mathrm{kg} / \mathrm{h}$; the parameters of the optimum region are as follows: $\mathrm{C}_{0}$ $=0.060 \mathrm{~m} / \mathrm{s}, n=320 \mathrm{~min}^{-1}, v=4.5 \mathrm{~m} / \mathrm{s}$.

\section{REFERENCES}

1. I.E. Priporov. Mekhaniko-tekhnologicheskoe obosnovanie protsessa razdeleniya komponentov vorokha semyan podsolnechnika na vozdushno-reshetnykh zernoochistitel'nykh mashinakh [Engineering substantiation of separation of heap of sunflower grains on air-and-screen grain cleaners]: monograph. Krasnodar, KubGAU, 2016.

2. V.D. Shaforostov, A.A. Tyurin, A.V. Isaev, E.A. Peretyagin. Rezul'taty ispol'zovaniya semyaochistitel'noi mashiny MVU-1500 (MVR-4) na podgotovke semyan podsolnechnika [Test data report of MVU-1500 (MVR-4) grain cleaner upon preparation of sunflower grains]. Nauchno-tekhnicheskii byulleten' Vserossiiskogo VNII maslichnykh kul'tur, vol. 1, no. 123, pp. 72-76, 2005.

3. I.V. Serdyuchenko, A.G. Koshchaev, N.N. Guguchvili, I.S. Zholobova, I.M. Donnik, A.M. Smirnov, B.V. Usha. Microbiocenosis of the intestinal tract of honey bees and its correction. OnLine Journal of Biological Sciences, vol. 18, no. 1, pp. 74-83, 2018.

https://doi.org/10.3844/ojbsci.2018.74.83

4. A.G. Koshchaev, I.V. Shchukina, A.V. Garkovenko, E.V. Ilnitskaya, V.V. Radchenko, A.A. Bakharev, L.A. Khrabrova. Allelic variation of marker genes of hereditary diseases and economically important traits in dairy breeding cattle population. Journal of Pharmaceutical Sciences and Research, vol. 10, no. 6, pp. 1566-1572, 2018.

5. I.P. Saleeva, V.S. Lukashenko, A.G. Koshchaev, V.G. Volik, D.Y. Ismailova. Quality of Broiler Chicken Meat with the Use of Various Methods of Growing. Journal of Pharmaceutical Sciences and Research, vol. 10, no. 11, pp. 2979-2984, 2018.

6. A.N. Troshin, P.D. Onischuk, A.G. Koshchaev, S.P. Kudinova, O.V. Koshchaeva, V.Y. Nikitin, A.S. Krivonogova. Parameters of acute toxicity of the Ferro-Quin iron-sorbitol-protein complex. International Journal of Pharmaceutical Research, vol. 10, no. 4, pp. 784-790, 2018. https://doi.org/10.31838/ijpr/2018.10.04.136

7. D.A. Nikitin, V.G. Semenov, L.P. Gladkikh, V.G. Tyurin, A.G. Koshchaev, R.V. Chus, S.V. Shabunin. Ensuring the health and productivity of pigs with new immunotropic preparations. International Journal on
Emerging Technologies, vol. 10, no. 2, pp. 328-332, 2019.

8. I.A. Loshkomoinikov. Possibilities to increase production amounts of high protein feeds and their efficient use upon feeding cattle and poultry. Doctoral thesis. Omsk, Omsk Agrarian University, 2009. Retrieved from: http://www.lib.ua-ru.net/diss/cont/454439.html

9. A.G. Koshchaev, Y.A. Lysenko, A.A. Lysenko, A.V. Luneva, I.P. Saleeva, V.I. Fisinin. Screening of microorganism symbiont strains as a base of probiotics for poultry industry. Journal of Pharmaceutical Sciences and Research, vol. 9, no. 8, pp. 1373-1379, 2017.

10. A.A. Bakharev, O.M. Sheveleva, K.A. Fomintsev, K.N. Grigoryev, A.G. Koshchaev, K.A. Amerkhanov, I.M. Dunin. Biotechnological characteristics of meat cattle breeds in the Tyumen region. Journal of Pharmaceutical Sciences and Research, vol. 10, no. 9, pp. 2383-2390, 2018.

11. I.S. Koba, A.A. Lysenko, A.G. Koshchaev, A.K. Shantyz, I.M. Donnik, V.I. Dorozhkin, S.V. Shabunin. Prevention of mastitis in dairy cows on industrial farms. Journal of Pharmaceutical Sciences and Research, vol. 10, no. 10, pp. 2582-2585, 2018.

12. A.N. Ratoshny, A.A. Soldatov, S.I. Kononenko, I.N. Tuzov, A.G. Koshchaev. Organization of feeding dairy cows for preventing metabolic disorders. Journal of Pharmaceutical Sciences and Research, vol. 10, no. 12, pp. 3273-3276, 2018.

13. L.N. Skvortsova, A.G. Koshchaev, V.I. Shcherbatov, Y.A. Lysenko, V.I. Fisinin, I.P. Saleeva, S.F. Sukhanova. The use of probiotics for improving the biological potential of broiler chickens. International Journal of Pharmaceutical Research, vol. 10, no. 4, pp. 760-765, 2018. https://doi.org/10.31838/ijpr/2018.10.04.132

14. E.I. Anisimova, A.G. Koshchaev, O.N. Eremenko, A.S. Krivonogova, K.V. Plemyashov, T.V. Kalashnikova, S.V. Shabunin. Economic efficiency of productive features of various dairy cattle genotypes. International Journal of Innovative Technology and Exploring Engineering, vol. 8, no. 8, pp. 3207-3211, 2019.

15. V.N. Vasilenko. Scientific support of production of coextruded and expanded complete feeds: Abstract of doctoral thesis. VGTA, Voronezh, 2010.

16. M.I. Zverzhanovskiy, S.N. Zabashta, T.S. Kataeva, A.G. Koshchaev, M.V. Nazarov. Epizootic trichinellosis situation and consortive links in jackals (Canis aureus L.) in North-western Region of Russia. Indian Veterinary Journal, vol. 94, no. 10, pp. 29-32, 2017.

17. A.V. Garkovenko, V.V. Radchenko, E.V. Ilnitskaya, A.G. Koshchaev, I.V. Shchukina, A.A. Bakharev, S.F. Sukhanova. Polymorphism of cattle microsatellite complexes. Journal of Pharmaceutical Sciences and Research, vol. 10, no. 6, pp. 1545-1551, 2018.

18. A.G. Koshchaev, T.A. Inyukina, N.N. Guguchvili, Y.A. Makarov, A.M. Gulyukin, O.P. Neverova, V.N. 
Igor Evgenievich Priporov et al., International Journal of Emerging Trends in Engineering Research, 8(1), January 2020,157 - 163

Shevkopljas. The influence of metabolic products of Echinococcus granulosus on the oxidation processes in the organism of pigs. Journal of Pharmaceutical Sciences and Research, vol. 10, no. 9, pp. 2317-2325, 2018.

19. E.I. Anisimova, A.G. Koshchaev, A.A. Nesterenko, A.A. Bakharev, A.G. Isaeva, T.M. Shuvaeva, T.V. Kalashnikova Comparative Assessment of The Relationship Between Intrabreed Types of Simmental Cows And Sectionized Traits. International Journal of Pharmaceutical Research, vol. 10, no. 4, pp. 604-610, 2018.

20. I.G. Kiselev, I.A. Rodin, A.N. Bezin, A.A. Stekolnikov, A.G. Koshchaev, M.G. Yakovets, A.S. Krivonogova. Clinical aspects of the use of smooth and full-threaded rods of the VOSIS veterinary orthopedic set in cats. International Journal of Innovative Technology and Exploring Engineering, vol. 8, no. 8, pp. 3212-3215, 2019.

21. V. Gorshkov. Granulirovanie podsolnechnogo zhmykha pered ekstraktsiei [Pelletizing of sunflower meal prior to extraction]. Kombikorma, vol. 5, pp. 34-36, 2014.

22. A.G. Koshchaev, Y.A. Lysenko, A.V. Luneva, A.N. Gneush, M.V. Aniskina, V.I. Fisinin, I.P. Saleeva. Studying biological activity of Lactobacillus hydrolysates. Journal of Pharmaceutical Sciences and Research, vol. 10, no. 10, pp. 2475-2479, 2018.

23. N.I. Kryukov, V.O. Yurchenko, A.G. Koshchaev, N.E. Gorkovenko, D.P. Vinokurova, A.A. Bogosyan, S.F. Sukhanova. The Derivative of Prussian Blue Paint Khzh-90 Cesium Isotopes' Sorbent At Mycotoxicoses. International Journal of Pharmaceutical Research, vol. 10, no. 4, pp. 669-674, 2018.

24. I.N. Tuzov, V.G. Ryadchikov, A.N. Ratoshniy, N.I. Kulikova, A.G. Koshchaev. Using Holstein Cattle in Conditions of the Krasnodar Territory. Journal of Pharmaceutical Sciences and Research, vol. 10, no. 12, pp. 3160-3163, 2018.

25. S.V. Svistunov, N.N. Bondarenko, A.G. Koshchaev, D.A. Normov, V.N. Shevkopljas, O.P. Neverova, A.M. Smirnov. Productive qualities of gray mountain caucasian bees of type Krasnopolyansky. International Journal of Innovative Technology and Exploring Engineering vol. 8, no. 7, pp. 631-635, 2019.

26. A.N. Ostrikov, V.N. Vasilenko. Production line of complete extruded feeds. RF Patent 2328171, Byul. № 19, July 10, 2008.

27. A.G. Koshchaev, Y.A. Lysenko, M.P. Semenenko, E.V. Kuzminova, I.A. Egorov, E.J. Javadov. Engineering and development of probiotics for poultry industry. Asian Journal of Pharmaceutics, vol. 12, no. 4, pp. 1179-1185, 2018.

28. V.G. Tyurin, V.G. Semenov, D.A. Nikitin, A.V. Lopatnikov, I.N. Madebeikin, A.G. Koshchaev, O.V. Koshchaeva. Stimulation of adaptogenesis in aberdeen-angus calves for improving productive qualities. International Journal of Engineering and Advanced Technology, vol. 8, no. 5, pp. 440-444, 2019.
29. Y.A. Yuldashbaev, S.O. Chylbak-Ool, A.G. Koshchaev, T.A. Inyukina, S.V. Shabunin, O.G. Lorets, A.K. Karynbayev. Dependence of the physicochemical composition and biological value of the meat of tuvinian short-fattailed sheep on the type of feeding behavior. International Journal of Engineering and Advanced Technology, vol. 8, no. 6, pp. 5161-5166, 2019. https://doi.org/10.35940/ijeat.F9102.088619

30. A. Ostrikov, V. Vasilenko. Ekstrudirovanie kombikormov: novye podkhody i perspektivy [Extrusion of combined feeds: new approaches and challenges]. Kombikorma, vol. 8, pp. 39-42, 2011.

31. A.N. Troshin, A.N. Turchenko, P.D. Onischuk, A.G. Koshchaev, S.P. Kudinova, A.Y. Shantyz, O.V. Koshchaeva. Long-term use of iron-mineral and iron-organic drugs. International Journal of Pharmaceutical Research, vol. 10, no. 4, pp. 791-797, 2018.

32. V.G. Semenov, D.A. Nikitin, A.V. Volkov, V.G. Tyurin, A.G. Koshchaev, A.A. Nesterenko, S.V. Shabunin. Preventing Shipping Stress in Imported Heifers with the Use of Immunocorrection. International Journal of Innovative Technology and Exploring Engineering, vol. 8, no. 5, pp. 1591-1595, 2019.

33. N.I. Kulikova, O.N. Eremenko, A.G. Koshchaev, T.V. Kalashnikova, N.V. Evdokimov, K.A. Amerkhanov, I.M. Dunin. Productive longevity of holstein bulls' female offspring. International Journal of Engineering and Advanced Technology, vol. 8, no. 5, pp. 435-439, 2019.

34. A.G. Koshchaev, R.A. Shichiyakh, M.V. Sidorenko, A.A. Kulik, S.N. Kharchenko, N.M. Bat. Development of bioproductive soil mixtures using subway construction waste for the purpose of improving the territory of the city. International Journal of Engineering and Advanced Technology, vol. 8, no. 6., pp. 5318-5327, 2019. https://doi.org/10.35940/ijitee.F9160.0981119

35. I.E. Priporov. Method of production of protein feed. RF Patent 2636474, Byul. № 33, November 23, 2017.

36. I.E. Priporov. Usovershenstvovannaya tekhnologiya polucheniya belkovogo korma iz semyan podsolnechnika (zhmykha) [Improved technology of protein feed based on sunflower seeds (meal)]. Vestnik VSGUTU, vol. 1, no. 68, pp. 47-53, 2018.

37. S.V. Mel'nikov, V.R. Aleshkin, P.M. Roshchin. Planirovanie eksperimenta $\mathrm{v}$ issledovaniyakh sel'skokhozyaistvennykh protsessov [Design of experiments in studies of agricultural processes]. Kolos, Leningrad, 1980.

38. V.V. Tsybulevskii. Canonic transform Bk-2; RF Certificate 2004612245, October 4, 2004. 